\title{
Public-Private Partnership in Building Sustainable Development of the Kuyavian- Pomeranian Voivodship
}

\author{
Agnieszka Huterska \\ Faculty of Economic Sciences and Management \\ Nicolaus Copernicus University, Poland
}

\begin{abstract}
The main purpose of the article is to present both the implemented and conducted projects within the framework of public-private partnership. It discusses the influence of the activities undertaken by the local authorities on both the natural environment and the economic aspects of human life. Potential effects of project implementation within the public-private partnership in the Kuyavian-Pomeranian voivodship (province) on the development of the Voivodship are presented. Due to the difficult situation in the region, the citizens' expectations to conduct investments and limited possibilities of increasing income, implementing projects within public-private partnership seems to be a favourable solution.
\end{abstract}

Keywords: public-private partnership, sustainable development

\section{Introduction}

The main purpose of the article is to present both the implemented and conducted projects and project ideas within the framework of public-private partnership. The probable influence of the presented project ideas in the Kuyavian-Pomeranian Voivodship (province) on the sustainable development of the Voivodship is indicated. The main research methods are the descriptive method and case study including the analysis of the projects conducted within the Public-Private Partnership in Poland including the Kuyavian-Pomeranian Voivodship in particular.

\section{The Concept of Sustainable Development}

The concept of sustainable, self-sustaining development was used for the first time in a document of the World Nature Organization in 1980. Three years later, in 1983, the United Nations General Assembly established the World Commission on Environment and Development, called after its Chairwoman the Brundtland Commission. The Commission was supposed to analyse the main tendencies resulting from economic development and the shrinking of natural resources. "Our Common Future", the Report of the Commission approved in 1987, advocated the need for such economic development that would be consistent with the principles of the management of natural environment. Emphasis was shifted from the protection of natural resources to satisfying basic needs of societies, poverty eradication and promoting civilizational development, leaving to future generations the possibility of choosing their way of development (StawickaWałkowska, 2001, p. 6).

Sustainable development means "a balance in ecosystems (ecological balance) and an equilibrium between economic, ecological and social aspects of economic development, that is, in other words, it guarantees political, economic, spatial and social governance, while the needs of future generations are also considered. Therefore, sustainable development should eradicate poverty and guarantee intra- and intergenerational social justice" (Górka, 2010, p. 11). "Sustainable development constitutes a long-term objective of socio-economic development of the European Union" (Górka 2010, p. 15). Taking care of the natural environment, which is manifested in among others respecting natural resources, is also an element of sustainable development (Łapińska, Huterska, Łapiński, 2017, p. 99). Territorial expansion, so typical for the functioning of contemporary cities, which leads to exploiting nature's resources on the area of expansion (Huterska, Huterski, 2014, p. 135), should also take into consideration the assumptions of sustainable development. It can concern for instance revitalisation of decaying buildings and green areas in cities. 
The role of local communities in implementing the rules of sustainable development was indicated in the Action Programme - Agenda 21 adopted during the United Nations Conference on Environment and Development held in Rio de Janeiro from $3^{\text {rd }}$ to $14^{\text {th }}$ June 1992 (Górka, 2010, p. 21). The document includes among others social and economic issues such as poverty eradication, protection and promotion of human health, promoting permanent and sustainable development of human settlements, protection and management of natural resources in order to guarantee permanent and sustainable development, also complex planning and management of the Earth's natural resources, strengthening the role of nongovernmental organisations - partners in activities promoting permanent and sustainable development, strengthening the role of business and industry towards the achievement of permanent and sustainable development (Agenda 21).

The features of permanent and sustainable development include (Stawicka-Wałkowska, 2001, pp. 7-8):

sustainability, which means the necessity to maintain the correct proportion of the balance of human development needs with the need to protect the environment and its resources,

permanence, which concerns the changes of natural environment, which needs to be revalued, protected and shaped rationally,

self-sustainability of development (in terms of maintaining reserves and creating new incentives for further development), achieved through respecting natural resources.

The natural environment and spatial planning, including the type of building, infrastructure, socio-cultural structure connected with economic and political conditions, has a considerable impact on the quality of human life (StawickaWałkowska, 2001, p. 8).

During Habitat II, the United Nations Conference on Human Settlements, which took place in Istanbul in June 1996, the necessity to connect human issues such as guaranteeing decent living, working and resting conditions and economic governance with ecological governance was indicated, which would enable living in safe and healthy environment, in harmony with nature, being held responsible for its self-regeneration and development, avoiding degradation of the natural environment (Stawicka-Wałkowska, 2001, p. 9).

The Resolution of the Sejm (the lower house of parliament) of the Republic of Poland of $2^{\text {nd }}$ March 1991 obligated the government to submit Strategy for Sustainable Development of Poland by $30^{\text {th }}$ June 1999. It was supposed to specify the directions of the country's development until 2015. According to the Resolution, sustainable development was understood as such a model of development in which satisfying current social needs and the needs of future generations would be considered equal. The strategy was to harmoniously combine efforts to preserve the nation's natural and cultural heritage with progress in civilisation and economy enjoyed by all social groups (Strategia zrównoważonego rozwoju, 1999, p. 2).

Local governments received basic tools for implementing sustainable development strategy, that was creating development strategy, spatial planning, issuing location decisions and permits for using natural resources and introducing changes in it (Strategy for Sustainable Development of Poland, 1999, p. 22). The Strategy was in force until 2007, when a resolution of the Council of Ministers of $23^{\text {rd }}$ October 2007 made it inapplicable (Ministerstwo Rozwoju Regionalnego, 2007, p. 78).

Human construction activities involve significant degradation of the natural environment (Stawicka-Wałkowska, 2001, $p$. 23). It results from the necessity to consume the resources concerning among others using areas for construction purposes or direct consumption of resources.

Modernisation and rehabilitation of buildings has also become an element of sustainable management of built-up areas (Stawicka-Wałkowska, 2001, p. 56). Through using already existing, often devastated buildings, it enables the limitation of further human expansion on new areas and it prevents creating degraded areas in cities.

\section{Public-Private Partnership}

Civilizational progress "expands the scope of public activities and the responsibility of the State for the socio-economic development, which the functioning of technical and social infrastructure and public entities do not keep pace with" (Perkowski, 2004, p. 97; Górka, 2010, p. 24). Attention is drawn to the fact that the private sector has infrastructural and financial effectiveness adequate to the implementation of such tasks (Perkowski, 2004, p. 97). 
Cooperation of a public body, for instance of a municipality, with a private partner aims at enabling efficient execution of tasks conferred to a public entity (Prekowski, 2004, p. 97). It seeks to execute a specific business task, whereby nowadays public-private partnership is not limited to the traditional central government, a local government and the private sector. Nowadays partnership concerns also social, educational and health groups, many of which have been financed with both public and private funds (Geddes, 2016, p. 1).

The rules governing the cooperation between a public entity and a private partner within public-private partnership are specified by the Act of $19^{\text {th }}$ December 2008 on public-private partnership, Journal of Laws of 2015, item 696 as amended. Within the frames of public-private partnership, a public entity and a private partner jointly execute a specific project sharing tasks and risks (Art. 1 Point 2).

According to the aforementioned Act, the public entity is (Art. 2 Point 1 of the Act of $19^{\text {th }}$ December 2008 on public-private partnership, Journal of Laws of 2015, item 696 as amended):

- $\quad$ a unit of the public finance sector as specified in the provisions on the public finance,

- a legal person established in order to satisfy the needs common in nature, neither industrial, nor commercial ones,

- $\quad$ if the abovementioned entities, individually or jointly, directly or indirectly through another entity:

- finance it in over $50 \%$ or

- own more than a half of shares or stocks, or

- $\quad$ supervise the managing body, or

- are entitled to appoint more than a half of the composition of the supervisory or managing body,

- and unions of those entities.

- The Act specifies the private partner as an entrepreneur or a foreign entrepreneur.

- The following projects can be implemented within the framework of public-private partnership:

- construction or renovation of a building,

- providing services,

- performing a work, in particular providing an asset with equipment, which increases its value or usefulness, or

- $\quad$ other service - combined with the maintenance or management of an asset that is used for the implementation of a public-private project or is connected with it (the Act on public-private partnership, Art. 1 Point 4).

The benefits resulting from the implementation of specific projects within the framework of public-private partnership include among others sharing risks, lowering the costs and value of services, increasing the quality of services, improving the condition of infrastructure, beneficial budgetary consequences, strengthening the stimulating function of the public finance, and improving administration standards. However, apart from the benefits of project implementation within public-private partnership, threats can appear, such as "weakening or loss of public control over a project, uncontrolled increase of prices, unreliability of a private partner, unavailability of competition, lowering the quality of services, disturbances of smoothness of services, disturbances and conflicts on the local labour market, long-term contractual burden, identification difficulties in responsibility for execution of public tasks, the risk of political misunderstandings, sensitivity of services concerned (e.g. water or electricity supply), allegations of corruption, limiting the development potential to the agreed framework only" (Perkowski, 2004, p. 98).

\section{Projects Implemented within the Framework of Public-Private Partnership}

Projects implemented by a public entity in cooperation with a private partner can enable satisfying the needs of a society, poverty eradication, and the improvement of the comfort of citizens' life, even when the investment possibilities of the local government unit are limited.

As far as the unemployment rate is concerned, the situation of the Kuyavian-Pomeranian Voivodship does not look that good. The unemployment rate in Poland at the end of 2017 amounted to $8.6 \%$, but $12.5 \%$ in the Kuyavian-Pomeranian Voivodship, including $8.4 \%$ in Bydgoszcz County, $5 \%$ in Bydgoszcz, $14.7 \%$ in Toruń County, $6.3 \%$ in Toruń, $17.2 \%$ in Grudziądz County, 22.6\% in Włocławek County, 21.69\% in Lipno County, and 16.9\% in Wąbrzeźno County (Wojewódzki Urząd Pracy). 
In accordance with the budgets adopted in the two biggest cities of the Kuyavian-Pomeranian Voivodship, in 2017 in the city of Torun the deficit of PLN 101,500,000 is predicted with planned income of PLN 1,083,200,000, in the city of Bydgoszcz the predicted deficit amounts to PLN 176,864,925 with planned income of PLN 1,875,162,071 for the year 2017 (Uchwała nr 490/16 RMT, Uchwała nr XXXVIII/740/16). Both Torun and Bydgoszcz obtained a favourable opinion of the Regional Chamber of Audit considering the possibilities of financing the planned deficits presented in the budget resolution of the City of Bydgoszcz and the City of Torun for the year 2017 (Uchwała nr 11/D/2017, Uchwała nr 1/D/2017). However, in the opinion concerning Bydgoszcz, it was emphasised that long-term liabilities for financing deficit planned for the year 2017 would influence the city's situation in the years to come (Resolution No. 11/D/2017). Both in Torun and in Bydgoszcz numerous considerable investments chargeable to the budgets of the cities have been completed. Among them investments connected with public roads in cities with County rights can be found, and they include the construction of a road bridge in Torun with access roads, the construction of Trasa Średnicowa Północna (Cross-city North Route), the construction of Trasa Staromostowa (Old Bridge Route) from Plac Armii Krajowej (Armia Krajowa Square) to Plac Niepodległości (Independence Square), or the construction of a bridge in Bydgoszcz. The budget of the City of Torun includes investment expenditure for the purpose of considerable investments such as revitalisation of the urban park in Torun, revitalisation of Bulwar Filadelfijski (Philadelphia Boulevard) with the Vistula waterfront from the road bridge to the AZS marina, creating Innovation Centre, International Meeting Centre, Torun Technology Incubator, or the development of the Jordanki area for the cultural and congress purposes. The investments support the development of the city and influence the comfort of the citizens' life. Due to the difficult situation in the region, the citizens' expectations to conduct investments and limited possibilities of increasing income, implementing projects within public-private partnership seems to be a favourable solution.

Until the end of 2016, 122 contracts within public-private partnership were concluded and 142 investment plans were submitted in Poland. Table 1 presents projects in individual voivodships.

Table 1. Projects within public-private partnership

\begin{tabular}{|l|l|l|}
\hline Voivodship & $\begin{array}{l}\text { Number of concluded contracts } \\
\text { as on 31st December 2016 }\end{array}$ & $\begin{array}{l}\text { Number of investment plans } \\
\text { as on 28 }\end{array}$ \\
\hline Lower Silesian & 11 & 11 \\
\hline Kuyavian-Pomeranian & 3 & 3 \\
\hline Lublin & 2 & 0 \\
\hline Lubusz & 4 & 2 \\
\hline Łódź & 1 & 0 \\
\hline Lesser Poland & 5 & 12 \\
\hline Masovian & 23 & 3 \\
\hline Opole & 3 & 9 \\
\hline Subcarpathian & 3 & 0 \\
\hline Podlaskie & 1 & 0 \\
\hline Pomeranian & 12 & 8 \\
\hline Silesian & 19 & 14 \\
\hline Swiętokrzyskie & 3 & 15 \\
\hline Warmian-Masurian & 8 & 8 \\
\hline Greater Poland & 10 & 3 \\
\hline West Pomeranian & 5 & 10 \\
\hline In total & 122 & 142 \\
\hline
\end{tabular}

Source: Own study based on Baza zawartych umów PPP oraz Baza zamierzeń inwestycyjnych PPP, Platforma Partnerstwa Publiczno-Prywatnego,

http://www.ppp.gov.pl/baza/Strony/baza_projektow_ppp.aspx/project_base/35\#project-list [Accessed on 05.08.2017).

So far contracts for three projects have been concluded within public-private partnership in the Kuyavian-Pomeranian Voivodship. Three more investment plans have been submitted. The first of the concluded contracts considered selecting a Private Partner for the implementation of a project of building a municipal waste recovery plant in the Municipality of Żnin, the second one considered choosing an operator managing Toruń Technology Incubator. The third project consisted in selecting an operator managing the International Youth Meeting Centre in Toruń. 
The negotiated contracts belong to the sector of transport infrastructure and health care. They concern construction, reconstruction and maintenance of voivodship roads in Włocławek area, construction of an expressway from Torun to Bydgoszcz and design, construction and turn-key furnishing of a retirement home in the Municipality of Gostycyn.

\section{Summary}

Implementing projects within the framework of public-private partnership in the Kuyavian-Pomeranian Voivodship allows public entities, despite their limited financial possibilities, to perform their tasks such as improving the road infrastructure, environmentally friendly management of municipal solid waste, or supporting the creation and development of innovative ICT companies. It is also important for sustainable development of the City of Torun to create conditions for the development of information society in the region in the revitalised building of Młyny Toruńskie (Torun Windmills). The adaptation of the existing in the city centre zone buildings, easily accessible, will enable limitation of human expansion on new area; it will prevent marginalisation and slowing down of the central zone; it will also allow limited use of building materials needed for constructing new buildings as well as using already existing infrastructure in connection with among others infrastructure facilities.

In the ageing Polish society, it seems crucial to support such initiatives as creating within Public-Private Partnership a Senior Residence offering a cultural and educational function (art workshops, university of the third age), staff housing, guest rooms and a touristic and recreational building (a swimming pool, a spa, a hotel, a bowling alley, a restaurant) with necessary technical, touristic infrastructure and land use. Implementation of such projects will certainly improve the life conditions of not only elderly citizens of the region.

Due to the difficult situation in the region, the citizens' expectations to conduct investments and limited possibilities of increasing income, implementing projects within public-private partnership seems to be a favourable solution.

\section{Literature}

[1] Geddes, M., 2016. Making Public Private Partnerships Work : Building Relationships and Understanding Cultures. New York: Routledge, eBook Collection (EBSCOhost), EBSCOhost, viewed 11 August 2017.

[2] Perkowski, M., 2004. Efektywność ochrony środowiska a partnerstwo publiczno-prywatne w Unii Europejskiej. Prawo i Środowisko, 3 (39).

[3] Górka, K., 2010. Wdrażanie koncepcji rozwoju zrównoważonego. In: M. Burchard-Dziubińska, A. Rzeńca, ed. Zrównoważony rozwój na poziomie lokalnym i regionalnym. Teoria i praktyka. Łódź: Wydawnictwo Uniwersytetu Łódzkiego, pp. 10-25.

[4] Stawicka-Wałkowska, M., 2001. Procesy wdrażania zrównoważonego rozwoju w budownictwie. Prace Naukowe Instytutu Techniki Budowlanej, Wydawnictwo ITB, Warszawa 2001.

[5] Act of $19^{\text {th }}$ December 2008 on public-private partnership, Journal of Laws of 2015, item 696 as amended

[6] Agenda 21, sustainabledevelopment.un.org/content/documents/Agenda21.pdf [Accessed 10 April 2017]

[7] Strategia zrównoważonego rozwoju polski do roku do roku 2025, www.nape.pl/.../strategie/strategie/Strategia_zrownowazonego_rozwo... Ministerstwo Środowiska, Warszawa 1999, [Accessed 05 May 2017].

[8] Ministerstwo Rozwoju Regionalnego, Wykaz obowiązujących dokumentów strategicznych, , Warszawa December 2007, www.mrr.gov.pl/...strategiczne/.../Wykaz_dokumentow_1207.pdf [Accessed 15 April 2013].

[9] Baza Projektów Partnerstwa Publiczno-Prywatnego, Ministerstwo Gospodarki, http://bazappp.gov.pl/project_base/35\#project-list [Accessed 10 July 2017]

[10] Uchwała nr 490/16 RADY MIASTA TORUNIA z dnia 15 grudnia 2016 r. w sprawie budżetu miasta na rok 2017 Biuletyn Informacji Publicznej Urząd Miasta Torunia [online] Avaliable at: $<$ http://www.bip.torun.pl/dokumenty.php?Kod=10835> [Accessed 07 July 2017].

[11] Uchwała Nr XXXVIII/740/16 Rady Miasta Bydgoszczy z dnia 28 grudnia 2016 r. w sprawie uchwalenia budżetu miasta na 2017 rok, Biuletyn Informacji Publicznej Miasta Bydgoszcz [online] Avaliable at: $<$ http://www.bip.um.bydgoszcz.pl/na_skroty/finanse/budzet_miasta_bydgoszcz/budzet_miasta_2013/> [Accessed 07July 2017]. 
[12] Wojewódzki Urząd Pracy w Toruniu. Stopa bezrobocia. [online] Avaliable at: $<$ http://wup.torun.pl/urzad/statystyki/stopa-bezrobocia-w-wojewodztwie/>[Accessed 07July 2017].

[13] Uchwała Nr 11/D/2017 Składu Orzekającego Nr 2 Regionalnej Izby Obrachunkowej w Bydgoszczy z dnia 2 lutego 2017 roku w sprawie opinii o możliwości sfinansowania planowanego deficytu przedstawionego w uchwale budżetowej Miasta Bydgoszczy na 2017 rok, [online] Avaliable at: <http://www.bip.bydgoszcz.rio.gov.pl>[Accessed 07 July 2017].

[14] Uchwała Nr 1/D/2017 Składu Orzekającego Nr 14 Regionalnej Izby Obrachunkowej w Bydgoszczy z dnia 13 stycznia 2017 roku w sprawie wydania opinii o możliwości sfinansowania deficytu budżetu Miasta Torunia. [online] Avaliable at: <http://www.bip.bydgoszcz.rio.gov.pl> [Accessed 07 July 2017].

[15] Łapińska, J., Huterska, A., Łapiński, P., 2017. The financial effects of investments realised under sustainable development - the case of a Polish company representing the rendering industry. Roczniki Naukowe SERIA, tom XIX no. 1, pp. 99-103, [online] Avaliable at: <http://rn.seria.com.pl/rn/category/89-19-1.html>

[16] Huterska, A., Huterski, R., 2014. Wykorzystanie podatku od nieruchomości dla zrównoważonego rozwoju miast na przykładzie Torunia. Prace Naukowe Uniwersytetu Ekonomicznego we Wrocławiu, 330, pp. 135-147. 